dreves in šopov ter poškodbe vrhov ter delov krošenj. Lomljenje je bilo postopno, začelo se je po 15 . decembru, trajalo pa je skoraj en mesec.

V najbolj prizadetih delih gozdov je pozimi ležala dva do tri metre debela snežna odeja. Sneg se je stopil šele konec maja. Sistematičen pregled terenov v maju je pokazal, da je prizadetih precej več gozdov, kot smo sprva predvidevali.

Najbolj poškodovano območje je planota Pokljuke, predvsem destabilizirani sestoji, ki jih je prizadel že snegolom lata 2007. Snegolom leta 2008 je imel središče delovanja okoli 100 m višje kot tisti v letu 2007. Snegolom je v manjši meri prizadel tudi pretežno čiste smrekove sestoje na Mežakli (zgornji del), Jelovici (Martinček) in Karavankah (Belca). Najbolj prizadeta razvojna faza so drogovnjaki.

Predvsem pa so neugodne dodatne poškodbe v drogovnjakih, ki jih je zelo močno prizadel že snegolom

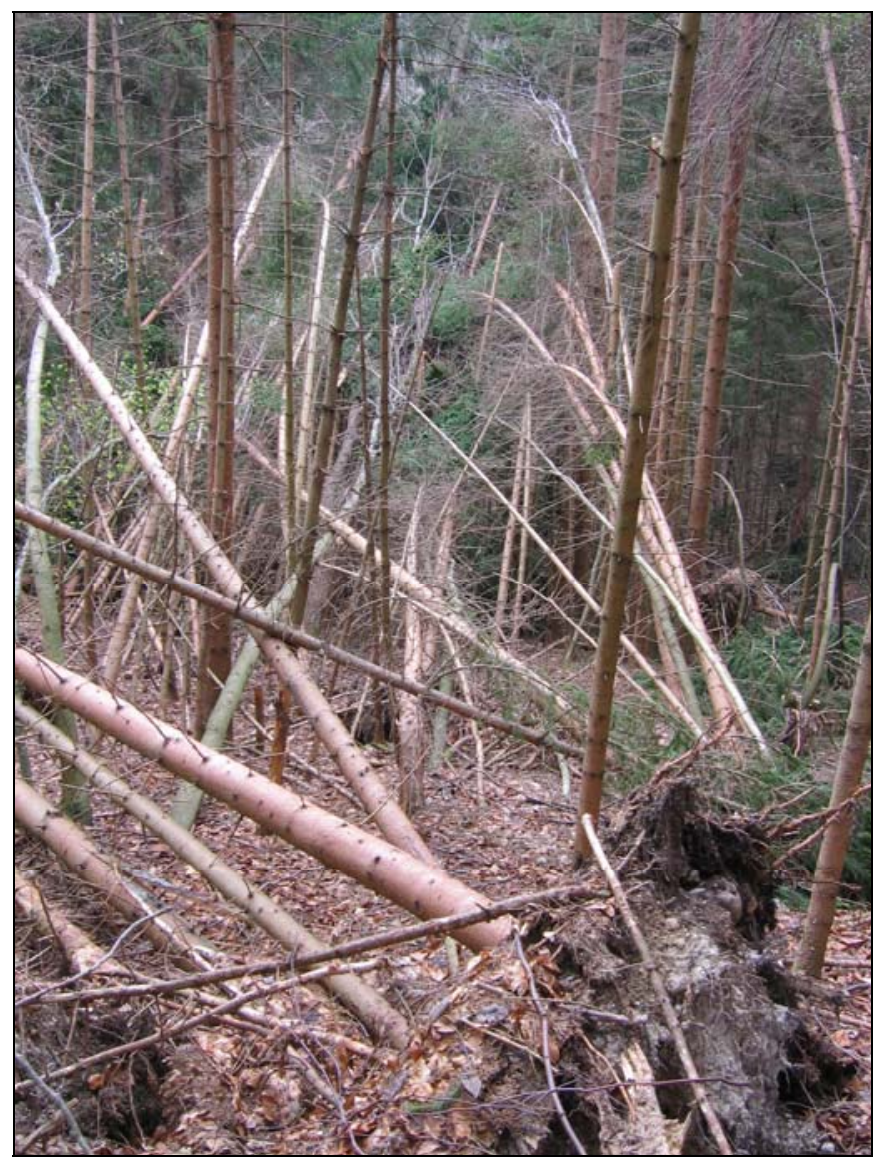

Slika 1: Posledice snegoloma v smrekovem drogovnjaku lata 2007. Sestojna zasnova in sklep sta se še poslabšala. Napad smrekovih lubadarjev na poškodovana drevesa je zelo močan, ker sta na poškodovanem območju zaradi pogostih naravnih ujm v zadnjih letih namnožena osmerozobi smrekov lubadar (Ips typographus) in šesterozobi smrekov lubadar (Pityogenes chalcographus).

\section{Viri}

Papler-Lampe V. 2009. Načrt sanacije gozdov poškodovanih v snegolomu decembra 2008. Zavod za gozdove Slovenije, Območna enota Bled

Zavod za gozdove Slovenije, Večna pot 2, 1000 Ljubljana *vida.papler-lampe@zgs.gov.si

\title{
Namnožil se je bukov rilčkar skakač - Rhynchaenus fagi
}

\section{Maja JURC $^{1 *}$, Marija KOLŠEK ${ }^{2}$}

V letu 2009 ugotavljamo namnožitev bukovega rilčkarja skakača (Rhynchaenus fagi). To je majhen, približno 2-3 mm dolg temno rjav hrošček $\mathrm{z}$ rilčkom, ki odskoči ob vsaki nevarnosti. Prisoten je povsod v Slo- veniji. Največ poškodb je povzročil na Gorenjskem in v osrednji ter jugovzhodni Sloveniji, kje so se zaradi njegove namnožitve $\mathrm{v}$ mesecu maju bukovi gozdovi ponekod jesensko obarvali. Pogosteje se pojavlja na 
toplejših prisojnih legah do $600 \mathrm{~m}$ nadmorske višine, ponekod tudi do $900 \mathrm{~m}$ n.m.v. Namnožitev je posledica zanj ugodnih vremenskih pogojev (višje povprečne temperature zraka in nizke količine padavin) $\mathrm{v}$ času odlaganja jajčec in razvoja ličink. Bukov rilčkar skakač lahko ob močnem napadu zmanjša letni prirastek bukve, vendar je življenjsko ne ogroža, zato ga ne zatiramo.

Bukov rilčkar skakač prezimi kot odrasel hrošček v stelji, listnem opadu, v razpokah skorje. Praviloma se v drugi polovici aprila ter v začetku maja hroščki selijo na mlade liste, ki se tedaj razpirajo in začno z zrelostnim (dopolnilnim) žrtjem, pri katerem luknjičasto brstijo liste (najdemo tudi po 5 ali 6 hroščkov na posameznem listu). Sredi maja začnejo njegove ličinke izjedati rove $\mathrm{v}$ listih od glavne listne žile proti robovom lista. V drugi polovici maja se pojavijo rjave mehurjaste izjedine na robovih bukovih listov, ki lahko zajemajo tudi do tretjino površine lista. Ko se $\mathrm{v}$ juniju razvijejo novi hroščki, ti spet objedajo listje. Najpogostejši gostitelj $R$. fagi je navadna bukev (Fagus sylvatica). Lahko se razvije na mnogih drugih listavcih (Alnus, Betula, Carpinus, Salix, idr). Areal bukovega rilčkarja skakača je celotna Evropa.

Namnožitve se pojavljajo nepričakovano, v dolgih in nepravilnih časovnih presledkih ter trajajo razmeroma kratek čas. Pogosto se gradacije že naslednje leto prekinejo, bukev pa spet normalno odžene. Prekinitev

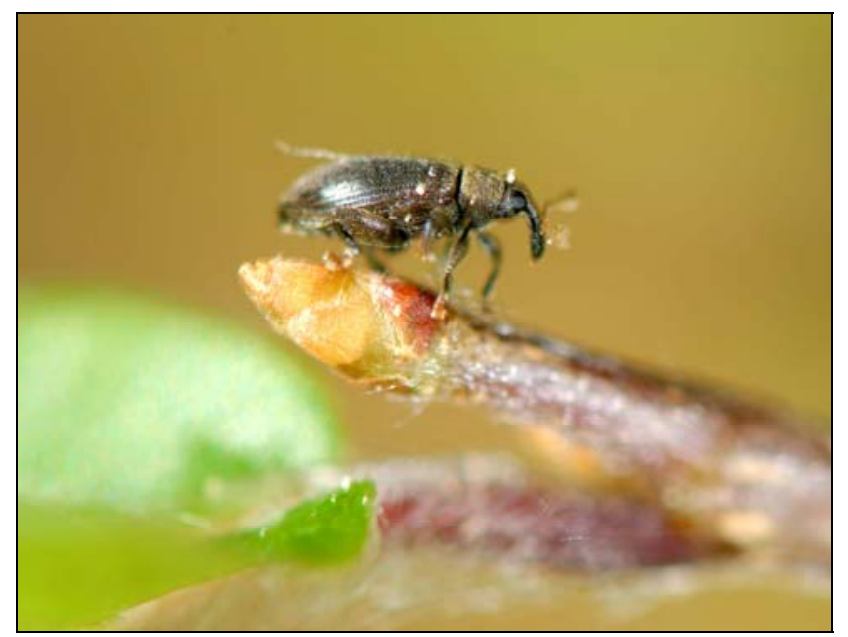

Slika 1: Bukov rilčkar skakač Rhynchaenus fagi (foto: Maja Jurc)

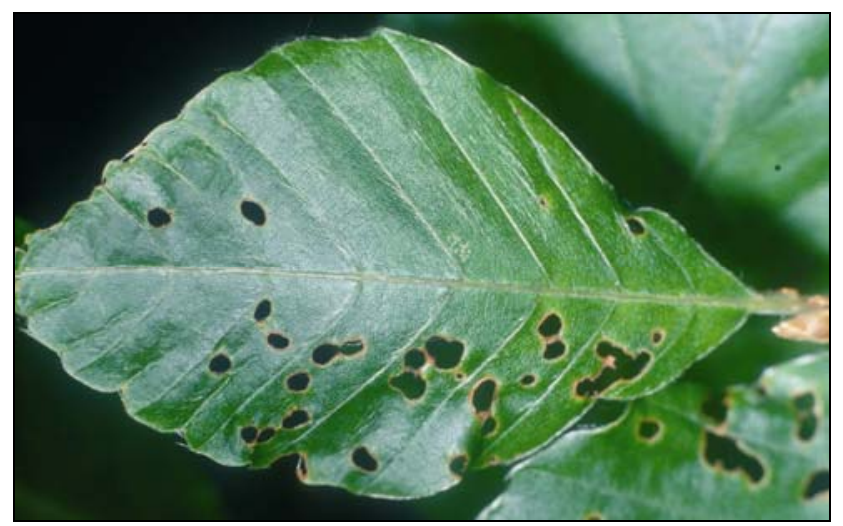

Slika 3: Poškodbe zaradi zrelostnega žretja hroščev Rhynchaenus fagi (foto: Maja Jurc) gradacij se zgodi po vsej verjetnosti zaradi neugodnih vremenskih razmer za bukovega rilčkarja skakača ali zaradi namnožitev njegovih naravnih sovražnikov.

V Sloveniji se je bukov rilčkar skakač pojavil v gradacijah v letih $1947,1963 / 64$ ter 1985/86. Leta 1986 je gradacija zajela celotna območja predalpskega, preddinarskega in predpanonskega fitogeografskega območja in tudi obrobja alpskega in dinarskega fitogeografskega območja. Pojavil se je na toplejših rastiščih navadne bukve v gričevnatem (do $600 \mathrm{~m} \mathrm{n.m.v.)} \mathrm{ter}$ pod montanskim vegetacijskim pasom $(600-900 \mathrm{~m}$ n.m.v.). V letu 2007 je bila ponovno zabeležena gradacija bukovega rilčkarja skakača. Posebej močno sta bili prizadeti Gozdnogospodarsko območje Ljubljana ter Gozdnogospodarsko območje Sežana.

\section{Viri}

Jurc M. 2007. Zdravje gozda, Navadna bukev - Fagus sylvatica (L.) Žuželke in pršice na listih. Gozdarski vestnik, 65, 5-6: 199-201

UUniverza v Ljubljani, Biotehniška fakulteta, Oddelek za gozdarstvo in obnovljive gozdne vire Večna pot 83, 1000 Ljubljana; ${ }^{2}$ Zavod za gozdove Slovenije, Centralna enota, Večna pot 2, 1000 Ljubljana *maja.jurc@bf.uni-lj.si

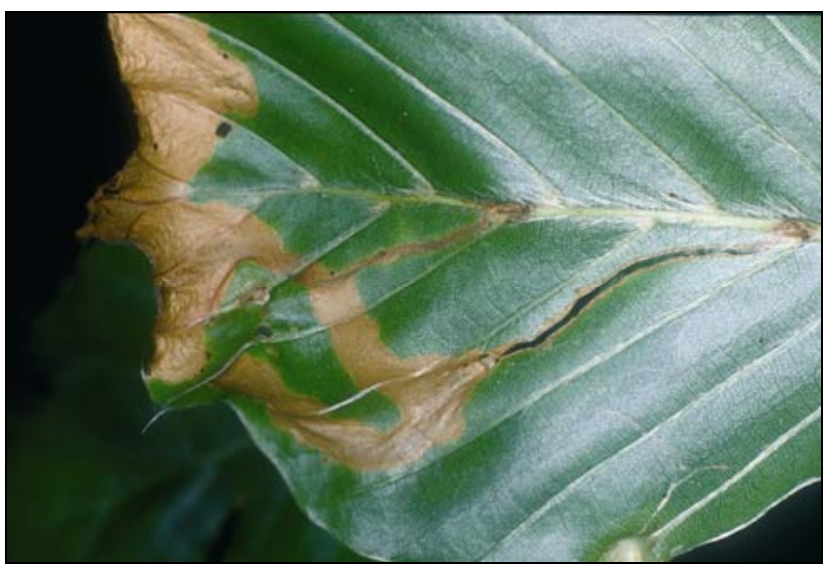

Slika 2: Poškodba lista navadne bukve zaradi ličink bukovega rilčkarja skakača (foto: Maja Jurc) 